\title{
Formulation and Evaluation of Fast Dissolving Tablet of Montelukast Sodium: Effect of Superdisintegrants
}

\author{
Mahant SA, Gaidhane AK*, Dokrimare NA, Wadher KJ, Lohiya RT, Umekar MJ
}

Department of Pharmaceutical Technology, Smt. KishoritaiBhoyar College of Pharmacy, Kamptee, Nagpur, India

DOI: $\underline{10.36347 / \text { sajp.2020.v09i02.006 }}$

| Received: 06.02.2020 | Accepted: 14.02.2020 | Published: 18.02.2020

*Corresponding author: Ms. Anjali K. Gaidhane

\section{Abstract}

Montelukast sodium is a selective, orally active leukotriene receptor antagonist drug used in the treatment of asthma in adults and children. It is rapidly absorbed after administration with a mean bioavailability of $73 \%$. There is a need to develop formulations which overcomes problems of Tablet as a dosage form, such as difficulty in swallowing, inconvenience in administration while travelling and dyspghagia. Hence in the present study an attempt has been made to prepare fast dissolving tablets of Montelukast sodium with enhanced dissolution rate. The tablets were prepared by direct compression method using with superdisintegrants. Direct compression is the most simple and economical method used in tableting. The simplicity of the direct compression process is apparent from a few steps involved in the manufacture of tablets as compared to wet granulation. The tablets were evaluated for hardness, drug content, friability and were found as per the specification. Drug content estimation showed that more than $95 \%$ of the drugs was present The highest drug release was obtained with the formulation F9 containing higher concentration of super disintegrants such as Sodiun starch glycolate and Crosspovidone.

Keywords: Montelukast sodium, Fast dissolving tablet, superdisintigrants, direct compression.

Copyright @ 2020: This is an open-access article distributed under the terms of the Creative Commons Attribution license which permits unrestricted use, distribution, and reproduction in any medium for non-commercial use (NonCommercial, or CC-BY-NC) provided the original author and source are credited.

\section{INTRODUCTION}

Montelukast sodium is a selective, orally active leukotriene receptor antagonist drug used in the treatment of asthma in adults and children. It is rapidly absorbed after administration with a mean bioavailability of $73 \%$ [1]. Convenience of administration and patient compliance are the important factor in the designing of dosage forms. Fast dissolving drug delivery systems generally dissolve or disintegrate within a minute, without water or chewing and include various dosage forms such as, tablets, logenzes, films/strips and microspheres etc [2]. Amongst the other dosage form, tablets are popular oral solid dosage forms due to its patient convienence, easy administration, stability, and compactness .Mouth dissolving drug delivery systems are suitable for the geriatric, pediatric, psychotic and for the patient suffering from dysphagia $[3,4]$. Significance of this system includes accuracy of dosage forms, administration without water, easy handling and rapid onset of action [5]. Direct compression is the most simple and economical method used in tableting. The simplicity of the direct compression process is apparent from a few steps involved in the manufacture of tablets as compared to wet granulation [6].
The objective of the present study was to prepare rapidly disintegrating tablets of Montelukast sodium by direct compression process with the aim to enhanced dissolution rate and improved patient compliance. The basic approach used in the development of mouth dissolving tablets is the use of super disintegrants.

\section{EXPERIMENTAL \\ MATERIALS AND METHODS}

Montelukast sodium (obtained assample fromSnehal Pharmaceuticals Pvt. Ltd, Nagpur) Sodium Starch Glycolate, Crosspovidone, Talc, Magnesium Stearate, Microcrystalline Cellulose used were of Pharmacopeial grade.

\section{Preparation of Montelucast Fast Dissolving Tablets}

Fast dissolving tablets of Montelukast were prepared by direct compression method using $3^{2}$ factorial design (Table-1). All the ingredients (as shown in Table-2) were powdered weight separately and passed through sieve no. 40 separately. Microcrystalline cellulose was used as diluent, talc as an antiadherent, and magnesium stearate as a lubricant. All the 
ingredients were blended together to get uniform mixture. Then the blend was compressed to get tablets of $100 \mathrm{mg}$ weight using rotary tablet machine [7]

Table-1: Factorial Design

\begin{tabular}{|l|l|l|}
\hline Batch & Crosspovidone & Sodium Starch Glycolate \\
\hline F1 & -1 & -1 \\
\hline F2 & 0 & -1 \\
\hline F3 & +1 & -1 \\
\hline F4 & -1 & 0 \\
\hline F5 & 0 & 0 \\
\hline F6 & +1 & 0 \\
\hline F7 & -1 & +1 \\
\hline F8 & 0 & +1 \\
\hline F9 & +1 & +1 \\
\hline
\end{tabular}

Table-2: Composition of Fast Dissolving Tablet

\begin{tabular}{|l|l|l|l|l|l|l|l|l|l|}
\hline \multirow{2}{*}{ Name of ingredient } & \multicolumn{8}{|c|}{ Formulation Batches (Quantity in mg) } \\
\cline { 2 - 12 } & F1 & F2 & F3 & F4 & F5 & F6 & F7 & F8 & F9 \\
\hline Montelukast sodium & 4 & 4 & 4 & 4 & 4 & 4 & 4 & 4 & 4 \\
\hline Crosspovidone & 2 & 4 & 6 & 2 & 4 & 6 & 2 & 4 & 6 \\
\hline Sodium Starch Glycolate & 2 & 2 & 2 & 4 & 4 & 4 & 6 & 6 & 6 \\
\hline Micro crystalline cellulose & 77 & 75 & 73 & 75 & 73 & 71 & 73 & 71 & 69 \\
\hline Sodium Saccharine & 10 & 10 & 10 & 10 & 10 & 10 & 10 & 10 & 10 \\
\hline Magnesium Stearate & 2 & 2 & 2 & 2 & 2 & 2 & 2 & 2 & 2 \\
\hline Talc & 3 & 3 & 3 & 3 & 3 & 3 & 3 & 3 & 3 \\
\hline
\end{tabular}

\section{Preformulation Studies}

Preformulation studies were carried out to determine the purity of the drug and any evaluation could also help to known if there is any detoriation of drug. It involve the determination of melting point, $\lambda$ max determination and determination of standard calibration curve of Montelukast.

\section{Melting Point of Drug}

Melting point determination of Montelukast by use in capillary tube method. Pure drug was placed in capillary tube which is fuse at one end and it is attached to the thermometer and dipped in capillary tube in liquid paraffin is added in Thiel's tube and heat the Thiel's tube above the burner and the temperature at which drug starts melting was noted.

\section{Evaluation of Oral Fast Dissolving Tablets}

Compressed tablets were then evaluated for hardness, Weight variation, disintegration, friability, and drug content.

\section{Weight Variation}

The Weight variation was determined by weighing 20 tablets using an electronic balance (Mettler Toledo) individually and collectively and calculating the average weight, and comparing the individual tablet weight to the average [8].

\section{Tablet Hardness}

The hardness of prepared tablets was determined by using Monsanto hardness tester. Three tablets from each formulation batch were tested randomly, and the average reading was noted. The hardness is measured in $\mathrm{kg} / \mathrm{cm}^{2}$ [9].

\section{Tablet Friability}

The friability of the tablets was measured in a Roche friabilator by using 10 tablets. The percentage friability of the tablets was measured as per the following formula $[10,11]$ :

Percentage friability $=\mathrm{W}_{1}-\mathrm{W}_{2} / \mathrm{W}_{1} \times 100$

Where,

$\mathrm{W}_{1}=$ Intital weight of tablet.

$\mathrm{W}_{2}=$ Final weight of tablet.

\section{Drug Content Uniformity}

Ten tablets were powdered and $10 \mathrm{mg}$ drug equivalent powder dispersed in phosphate buffer $\mathrm{pH} 6.8$ and analyzed in UV. The absorbance of the sample preparations was measured at $\lambda \max 283 \mathrm{~nm}$ for Montelukast sodium [12].

\section{Disintegration Test}

The in-vitro disintegration test was performed by using disintegration test apparatus. The test is carried out for total 6 tablets and distilled water at $37^{\circ} \mathrm{C} \pm 2{ }^{\circ} \mathrm{C}$ was used as a disintegration media. The time taken for the complete disintegration of the tablets was noted [13, 14].

\section{Dissolution Rate Study}

In vitro dissolution studies were performed for the tablets $(\mathrm{n}=6)$ using USP dissolution apparatus II ((LABINDIA, DISSO 8000) paddle type), at $50 \mathrm{rpm}$, 
thermostatically maintained at temperature $37 \pm 0.5^{\circ} \mathrm{C}$. Samples of dissolution fluid $(1 \mathrm{ml})$ were withdrawn through a filter at different time intervals and assayed for Montelukastat 283nm [15].

\section{RESULTS AND DISCUSSION}

Physicochemical Properties

Melting point of montelukast sodium by capillary tube method was found to be $148^{\circ} \mathrm{c}$. All the formulations were evaluated for weight variation, hardness, friability, thickness, disintegration and assay and their results are shown in Table-3.

\section{Evaluation of Fast Dissolving Tablet \\ Uniformity of thickness}

The Thickness of tablet ranged from $1.80 \pm 0.05-3.03 \pm 0.1 \mathrm{~mm}$, all the batches of tablets showed less deviation in thickness.

\section{Weight Variation Test}

The Average percentage deviation in weight of 20 tablet of each batch was less than \pm 10 . The tablets passed the USP limits.

\section{Hardness and Friability test}

Hardness of all formulations was between $3.7 \pm 0.6-5.2 \pm 0.1 \mathrm{~kg} / \mathrm{cm}$ and this was found satisfactory and within desired specification. Percentage Friability of all batches range from $0.13-0.96 \%$ (within the limit $<1 \%)$. The Hardness and Percent Friability indicates good mechanical strength of tablets.

\section{Drug content uniformity:}

Drug content of FDT of Montelukast was found to be between $86.3 \pm 0.50$ and $99.8 \pm 0.01 \%$ as shown in Table-3.

\section{Disintegration Time}

The in vitro disintegration time for all the compressed tablets was determined and results of all formulations are given in Table-3. Formulations F9, show good disintegration and drug release at $20 \mathrm{sec}$. All tablets disintegrated in less than 2 min.

Table-3: Post Compression Studies for Formulation of Fast Dissolving Tablets of Montelukast

\begin{tabular}{|l|l|l|l|l|l|l|l|}
\hline $\begin{array}{l}\text { Formulation } \\
\text { code }\end{array}$ & $\begin{array}{l}\text { Avg. } \\
\text { Wt.(g) }(\mathbf{n}=\mathbf{1 0})\end{array}$ & $\begin{array}{l}\text { Thickness } \\
(\mathbf{m m}) \mathbf{( n = 3 )}\end{array}$ & $\begin{array}{l}\text { Hardness } \\
\left(\mathbf{k g} / \mathbf{~ c m}^{2}\right)\end{array}$ & \%Friability & $\begin{array}{l}\text { \% Drug } \\
\text { content }\end{array}$ & $\begin{array}{l}\text { Disintegration } \\
\text { time }(\mathbf{s e c})\end{array}$ & $\begin{array}{l}\text { Dispersion } \\
\text { time }(\mathbf{m i n})\end{array}$ \\
\hline F1 & $0.107 \pm 0.7$ & $2.50 \pm 0.01$ & $5.2 \pm 0.1$ & 0.96 & $98.1 \pm 0.07$ & 82 & \\
\hline F2 & $0.103 \pm 0.8$ & $2.50 \pm 0.01$ & $4.07 \pm 0.5$ & 0.47 & $98.2 \pm 0.08$ & 72 & 1.15 \\
\hline F3 & $0.109 \pm 1.0$ & $2.47 \pm 0.03$ & $4.05 \pm 0.4$ & 0.54 & $99.8 \pm 0.01$ & 52 & 0.50 \\
\hline F4 & $0.110 \pm 0.5$ & $2.99 \pm 0.01$ & $4.2 \pm 0.2$ & 0.41 & $86.3 \pm 0.80$ & 60 & 1.25 \\
\hline F5 & $0.107 \pm 0.4$ & $1.80 \pm 0.05$ & $3.9 \pm 0.6$ & 0.13 & $88.3 \pm 0.71$ & 48 & 1.52 \\
\hline F6 & $0.104 \pm 1.2$ & $2.83 \pm 0.01$ & $4.7 \pm 0.5$ & 0.80 & $86.3 \pm 0.50$ & 44 & 1.36 \\
\hline F7 & $0.107 \pm 0.9$ & $3.03 \pm 0.1$ & $4.8 \pm 0.3$ & 0.81 & $94.4 \pm 0.12$ & 42 & 1.13 \\
\hline F8 & $0.105 \pm 0.7$ & $2.79 \pm 0.02$ & $4.8 \pm 0.2$ & 0.50 & $96.5 \pm 0.06$ & 33 & 1.29 \\
\hline F9 & $0.103 \pm 0.8$ & $2.4 \pm 0.05$ & $3.7 \pm 0.6$ & 0.87 & $99.8 \pm 0.01$ & 20 & 1.38 \\
\hline
\end{tabular}

In -vitro dissolution studies of Montelukast tablets in 6.8 pH Phosphate Buffer solution

It was observed from in vitro dissolution data, that an average of more than $75 \%$ of montelukast, released from all the formulations within $20 \mathrm{~min}$ indicates that the tablet complies as per pharmacopoeial specifications as shown in Figure-1. This indicates quick delivery of drug for systemic absorption. The highest concentration of disintegrant showed faster dissolution rate. The highest drug release was obtained with the formulation F8 and F9 containing higher concentration of super disintegrants Sodiun starch glycolate and Crosspovidone.

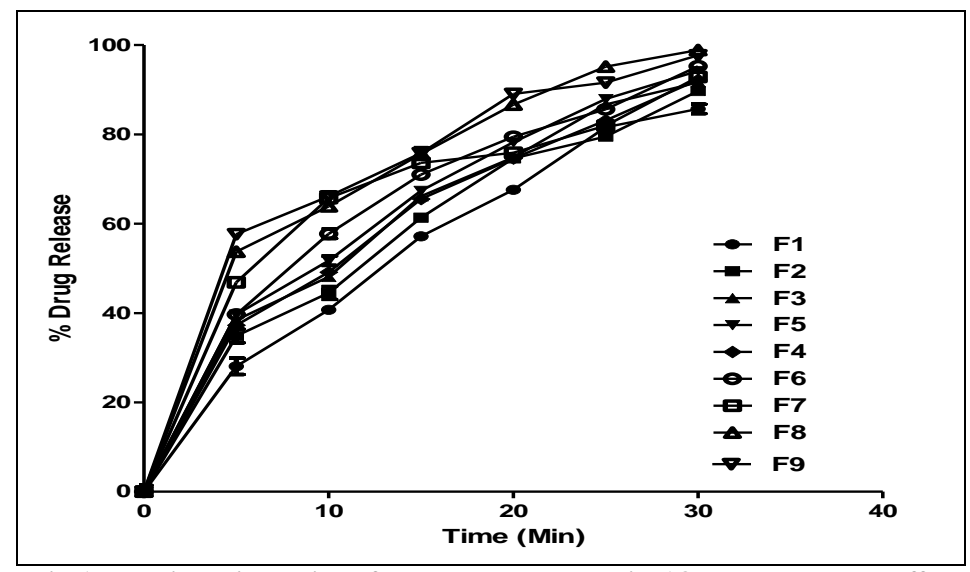

Fig-1: In -vitro dissolution of Montelukast tablets in $6.8 \mathrm{pH}$ Phosphate Buffer 


\section{CONCLUSION}

The aim of the research study was to design and develop a new formulation of orally disintegrating montelukast $4 \mathrm{mg}$ tablet by using direct compression method and by choosing the various types of superdisintigrants. Montelukast sodium tablets containing superdisintegrants exhibit quick disintegration and improved drug dissolution. It can be concluded from the present work that the type and concentration of SSG and Crosspovidon as superdisintegrants affects the disintigration and dissolution parameter of the tablets. The highest drug release was obtained with the formulation F8 and F9 containing higher concentration of super disintegrants Sodiun starch glycolate and Crosspovidone.

\section{REFERENCES}

1. Usmani MT, Shoaib MH, Nasiri MI, Yousuf RI, Zaheer K, Ahmed K. Development and Evaluation of Orally Disintegrating Tablets of Montelukast Sodium by Direct Compression Method.Tropical Journal of Pharmaceutical Research, 2010; 3(4): 803-808.

2. Wadher KJ, Umekar MJ, Sheikh GB, Younus M, Sapate RP, Fatima NF. Formulation and characterization of pediatric paracetamol oral mouth dissolving film. International Journal Res Pharm Sci, 2017; 8(3): 397-402.

3. Mahore JG, Wadher KJ, Umekar MJ. Formulation and in vitro Evaluation of Taste Masked Orodispersible Tablet of Metoclopramide Hydrochloride. International Journal Pharm Tech Res, 2010; 2(3): 1827-1835.

4. Seager H. Drug delivery products and the zydis fast dissolving dosage form. Journal Pharm Pharmacol, 1998; 50(4): 375-382.

5. Bradoo R, Shahani S, Poojary SM, Deewan B, Sudharshan S. An observed blind, randomized controlled clinical trial to compare the onset of action, efficacy and safety of citrizine flash tablets with oral loratidine and citrizine conventional tablets in allergic rhinitis. JAMA India, 2001; 4(10): 27-31.

6. Patel RP, Bhavsar M. Directly Compressible Materials via Co-Processing. International Journal Pharm Tech Res, 2009; 1(3): 745-753.
7. Mahesh E, Kiran Kumar GB, Mohammed GA, Kiran Kumar P, Formulation and Evaluation of Montelukast Sodium Fast Dissolving Tablets. Asian Journal of Biomedical and Pharmaceutical Sciences, 2012; 2(14): 75-82.

8. Jadhav SB, Kaudewar DK, Kaminwar GS, Jadhav AB, Kshirsagar RV, Sakarkar DM. Formulation and evaluation of dispersible tablets of diltiazem hydrochloride. International Journal of Pharm Tech Research, 2011; 3(3): 1314-1321.

9. Mahesh E, Kiran Kumar GB, Mohammed GA, Kiran Kumar P. Formulation and Evaluation of Montelukast Sodium Fast Dissolving Tablets. Asian Journal of Biomedical and Pharmaceutical Sciences, 2012; 2(14):75-82.

10. Suthar RM, Chotai NP, Shah DD. Formulation and Evaluation of Fast Dissolving Tablets of Ondansetron by Solid Dispersion in Superdisintegrants. Indian Journal of Pharmaceutical Education and Research, 2013; 47(3).

11. Sharma S, Kumar J, Arya A, Chandra A, Jaiswal P. Formulation and Evaluation of Mouth Dissolving Tablets of Ranitidine HCL. International Journal Pharm Tech Res, 2010; 2(2): 1574-1577.

12. Rawat P, Kumar P, Bisht T. Formulation and Characterization of Mouth Dissolving Tablet for Controlled Delivery of Ketoconazole. International Journal Pharma Res Health Sci, 2016; 4(6): 1495 1500 .

13. Sharma D, Singh M, Kumar D, Singh G. Formulation Development and Evaluation of Fast Disintegrating Tablet of Cetirizine Hydrochloride: A Novel Drug Delivery for Pediatrics and Geriatrics. Journal of Pharmaceutics, 2014.

14. Sharma D. Formulation Development and Evaluation of Fast Disintegrating Tablets of Salbutamol Sulphate for Respiratory Disorders. ISRN Pharmaceutics, 2013.

15. Anisree GS, Anu V, Rauof P, Megha V, Jouhara $\mathrm{OP}$, Abeera $\mathrm{CH}$. Design and evaluation of mouth dissolving tablet of levocetrizine hydrochloride; Scholars academic journal of pharmacy, 2014; 3(1),45-49. 